\title{
ОРОСЫН НИЙГМИЙН ТОГТВОРТОЙ БАЙДАЛД ХИЙСЭН ДУН ШИНЖИЛГЭЭ БА 2011 ОНЫ ТӨРИЙН ДУМЫН СОНГУУЛЬ
}

А.Нямдолжин

ОУСХ-ийн эрдэм шинжилгээний ахлах ажилтан, доктор /Ph.D/

\section{I. ОХУ-ын Төрийн Думын сонгууль, түүний дараа Үүссэн нөхцөл байдал}

ОХУ-ын Төрийн Думын зургаа дахь удаагийн сонгууль 2011 оны 12-р сарын 4-ний ням гаригт болж өнгөрлөө. Орос улс өнгөрсөн 4 жилийн хугацаанд сонгуулийн хуулиндаа нэлээд олон өөрчлөлт оруулжээ. Өмнө нь 4 жилийн хугацаатай Төрийн Думаа сонгодог байсан бол энэ удаа 5 жилийн хугацаатай сонгож, сонгуульд бүртгэлтэй улс төрийн бүх намууд оролцсоноороо онцлог болсон байна. 2007 оноос эхлэн Төрийн Думын гишүүдийг пропорциональ тогтолцоогоор буюу намын нэрсийн жагсаалтаар сонгож байгаа бөгөөд намууд Төрийн Думд суудал авахын тулд 7 хувийн босго давсан байх ёстой аж. 2011 оны 10-р сард сонгуулийн хуулинд оруулсан нэмэлт өөрчлөлтөөр энэ босгыг 5 болгож бууруулсан нь Медведевын тайлбарласнаар, “жижиг намуудад” парламентад төлөөлөлтэй байх боломж олгож, улс төрийн өрсөлдөөнийг илүү хүчтэй шударга болгох ач холбогдолтой алхам юм.

\begin{tabular}{|c|c|c|c|c|c|c|}
\hline \multirow[t]{2}{*}{ Байр } & \multirow[t]{2}{*}{ Намууд } & \multirow[t]{2}{*}{ Санал } & \multirow[t]{2}{*}{ Хувь } & \multirow[t]{2}{*}{$\begin{array}{l}\text { Дум дахь } \\
\text { суудал }\end{array}$} & \multicolumn{2}{|c|}{$\begin{array}{c}2007 \text { оны сонгуультай } \\
\text { харьцуулах нь }\end{array}$} \\
\hline & & & & & Хувь & \begin{tabular}{|l} 
Дум $\quad$ дахь \\
суудал
\end{tabular} \\
\hline 1 & $\begin{array}{l}\text { «Нэгдсэн } \\
\text { Орос» }\end{array}$ & 32379135 & $49,32 \%$ & 238 & $64.30 \%$ & 315 \\
\hline 2 & $\begin{array}{c}\text { «Коммунист } \\
\text { нам» }\end{array}$ & 12599507 & $19,19 \%$ & 92 & $11,57 \%$ & 57 \\
\hline 3 & $\begin{array}{c}\text { «Шударга } \\
\text { Орос» }\end{array}$ & 8695522 & $13,24 \%$ & 64 & $7,74 \%$ & 38 \\
\hline 4 & $\begin{array}{c}\text { «Либераль } \\
\text { ардчилсан } \\
\text { нам» }\end{array}$ & 7664570 & $11,67 \%$ & 56 & $8.14 \%$ & 40 \\
\hline 5 & «Яблоко » & 2252403 & $3,43 \%$ & 0 & $1,59 \%$ & 0 \\
\hline
\end{tabular}




\begin{tabular}{|c|c|c|c|c|c|c|c|}
\hline & \multicolumn{1}{|c|}{6} & $\begin{array}{c}\text { «Оросын эх } \\
\text { орончид» }\end{array}$ & 639119 & $0,97 \%$ & 0 & $0,89 \%$ & 0 \\
\hline 7 & $\begin{array}{c}\text { «Зөв Үйл } \\
\text { хэрэг» }\end{array}$ & 392806 & $0,60 \%$ & 0 & & \\
\hline $\begin{array}{l}\text { ХҮчинг } \\
\text { Үй } \\
\text { хуудас }\end{array}$ & 1033464 & $1,57 \%$ & - & & $\boldsymbol{\Delta} 0,52$ & \\
\hline & & & & & & & \\
\hline
\end{tabular}

Тус хууль 2013 оны 1-р сарын 1-нээс эхэлж хэрэгжиж эхлэх учраас энэ удаагийн сонгуульд оролцсон намууд дээрх “намсгасан босгыг” ашиглах боломжгүй байлаа. Хэдий тийм боловч 2009 онд хуулинд оруулсан нэмэлт өөрчлөлтөөр 5-6\%-ийн санал авбал 1 мандат, 6-7\%-ийн санал авбал 2 мандат авахаар болсон хэдий ч нэг ч нам энэ боломжийг ашиглаж чадсангүй.Сонгуулийн төв комиссын мэдээлснээр сонгуульд оролцсон 7 намын дөрөв нь сонгуулийн босгыг давж чадсан байна.1

Сонгуулийн дүнгээс харахад Төрийн Думын 450 суудлын 315 суудлыг эзэлж байсан “Нэгдмэл Орос” нам энэ удаа 238 суудал болтлоо буурсан нь том ухралт болж байна. Энэ нь оросын олон нийтийн санал бодол өөрчлөгдөж эхэлж байгааг харуулж байна. Ерөнхийлөгч Д.Медведев санал хураалтын дүнд сэтгэл хангалуун байгаагаа илэрхийлж, “нам нь сонгуульд боломжийн амжилт гаргасныг дурдаад “Нэгдмэл Орос” нам Дум дахь хамгийн хүчирхэг тэргүүлэгч улс төрийн хүчин гэдгээ дахин нотоллоо” гэж онцлон тэмдэглэсэн байна. Хэдийгээр Д.Медведев ийнхүҮ мэдэгдэж байгаа ч намын нэр хүнд буурахад тус улсын төрийн тогтолцоо нэлээд хатуу хяналттай болсон, шударга биш тогтолцоо бүрдсэн, авилга, хээл хахуулийн хэрэг хавтгайрч, инфляци тогтмол өндөр хувьтай гарч байгаа нь “Нэгдсэн Орос” намд итгэх итгэлийг сулруулж байгаа юм.

“Нэгдсэн Орос” намын гол сөрөг хүчин нь Коммунист нам болж байна. ОХУ-ын КН, ЗХУКН-ын гишүүд, анхан шатны байгууллагуудын санаачлагаар байгуулагдсан бөгөөд марксизм-ленинизмын үзэл санааг бүтээлчээр хөгжүүлж, хамт олонч үзэл, эрх чөлөө, тэгш эрх дээр үндэслэсэн социалист нийгэм, Зөвлөлүүдийн хэлбэрт жинхэнэ ардын эрхт төр байгуулж, олон үндэстний холбооны улсаа бэхжүүлэх зорилготой гэж тунхагласан тус нам зөвхөн зүүний үзэл баримтлалтай нам гэдгээрээ ч биш, сонгуулийн дүнг эсэргүүцэж байгаа хүмүүсийн дэмжлэгийг авсан гэдэг утгаараа яах аргагүй сөрөг хүчин мөн. Коммунист нам 
2007 оны сонгуулиар 11.6\%-ийн санал авсан бол энэ удаа 19.4\%-ийн дэмжлэг авсан нь өмнөхөөсөө бараг хоёр дахин илүү байгаа юм. Бусад намын хувьд ч мөн адил дэмжигчдийн тоо нь нэлээд нэмэгдсэн байна. Сонгуульд оролцсон байдлыг бүс нутгаар авч үзвэл алслагдсан, дэд бүтэц муу, буурай хөгжилтэй бүсүүд болох Дагестан, Ингушет, Чечень, Мордов, Чукотка, Карачево-Черкес, Тувад “Нэгдсэн Орос” намд өгсөн сонгуулийн саналын хувь өндөр, харин Москва, Санкт-Петербург ба Орос улсын хэмжээнд томд орох Свердловск, Хабаровск, Красноярск, Новосибирск, Челябинск, Доод Новгород, Самара хотуудад саналын хувь бага байв.

“Нэгдсэн Орос” намаас шинээр нэр дэвшиж, Төрийн Думд сонгогдсон гишүүдийн дотор улс төрөөс хол хөндий гэмээр урлаг, спорт, бизнесийн салбараас төлөөлөл ихээр орж ирсэн нь Орос орон цаашид ямар алхам хийж, хэрхэн хөгжих вэ гэдэг асуудал ч сонирхол татаж байна. Төрийн Думын хамгийн залуу гишүүн бол 27 настай жүжигчин, “Универ” хэмээх олон ангит уран сайхны киноны гол дүрийг бүтээсэн М.Кожевникова, ОХУ-ын ардын жүжигчин цолыг 2010 онд авсан “Вор” киноны гол дүрийг бүтээсэн 48 настай Владимир Машков, хүнд жингийн боксчин Николай Валуев, теннисний од 31 настай Марат Сафин, сонгомол барилдааны 3 удаагийн олимпын аварга Александр Карелин, уран гимнастикийн аварга А.Кабаева нар багтаж байгаа юм. Ерөнхий сайд В.Путин “Бүх холбоотын ардын фронт” байгуулан намын гишүүн бус хүмүүст сонгуульд оролцох боломжийг олгосны үр дүнд “Нэгдсэн Орос” намын фракцад энэ удаа хэний ч мэдэхгүй шинэ хүмүүс нэлээдгүй орж иржээ. Алдартнууд болон огт мэдэхгүй хүмүүсийг ийнхүУ Думд оруулж байгаа нь тусгай стратегийн нэгэн хэсэг бөгөөд тэд зүгээр л нэг шатрын хүүгийн үүргийг гүйцэтгэнэ хэмээн шүүмжлэгчид үзэж байгаа бөгөөд үнэхээр ч ийм олон жүжигчин, тамирчид яаж хууль тогтоох гэж байгаа юм бол гэсэн асуулт зайлшгүй гарч ирж байна. Тэгэхээр зүгээр л товчлуур дардаг хүмүүс болж таарч байгаа нь гарцаагүй. Үүний зэрэгцээ В.Путин “үндэсний баатруудаа” хэрхэн татаж ялалт байгуулахаа мэднэ гэж хэлсэн удаатай. "Үндэсний баатар” хэмээн цоллогдсон эдгээр хүмүүс Оросын нийгэмд үлгэр дуурайлал болж, улс төрийн намуудыг рекламдах гол хэрэгсэл болох нь тодорхой байна.

Сонгуулийг хуулийн дагуу шударга, зөрчил маргаангүй зохион байгуулах нь ардчилал шинээр тогтоосон улсуудын хувьд амин чухал асуудал бөгөөд ингэж чадаагүй нөхцөлд улс төрийн тогтвортой байдал сулрах, бүр даамжирвал нийгмийн эмх замбараагүй 
байдал газар авах хор уршигтай. Үүнийг Думын сонгуулийн дараа үүссэн нөхцөл байдал харуулж байна. Оросын иргэд шударга бус сонгууль боллоо хэмээн эсэргүүцлээ илэрхийлж, тэд эрх баригчдаас ерөнхий сайдыг огцорч, шударга сонгууль явуулж, сонгуулийн дүнг хүчингүйд тооцож, дахин сонгууль явуулах зэрэг шаардлага тавьсан байна. Энэхүу эсэргүүцлийн жагсаал цуглааны гол шалтгаан нь оросын ерөнхий сайд Владимир Путины тэргүүлдэг “Нэгдсэн Орос” нам сонгуульд дахин ялалт байгуулсан, мөн В.Путин 2012 оны Ерөнхийлөгчийн сонгуульд өрсөлдөнө гэдгээ албан ёсоор мэдэгдсэн нь “Путингүй Орос орон!”, “Өөр Орос орон”, “Шударга сонгуулийн төлөө” зэрэг хөдөлгөөн Москва, СанктПетербург болон олон арван хотуудад өрнөхөд хүргэсэн байна. Думын сонгуулийн дүнг эсэргүүцсэн иргэдийн жагсаал цагаан өнгөн дор нэгдэж, “Цагаан туузтан”- хөдөлгөөнүүд нь 12-р сарын 5, 6-нд 7 мянган хүний эсэргүүцлээр эхэлж, 10-нд 50 мянган хүн Намагт талбайд, 24-нд 120 мянган хүн академич Сахаровын өргөн чөлөөнд тус тус жагссан. Энэ нь зүгээр нэг эсэргүҮцэл биш, Оросын улс төрийн идэвхитэй бүх намын гишүүд төдийгүй нам бусчууд, гол нь Оросын дундаж давхаргынхан, оюуны элитүүд өргөнөөр жагсаалд оролцсон байна. 10-ны өдрийн жагсаалын дараа Оросын удирдагчид нойрмог олонхи, эрх баригчдыг дэмжигч массын хүрээнээс халин, Оросын эдийн засаг улс төрийн хамгийн идэвхтэй цөөнх нийгмийн үлдсэн хэсгээ сэрээж эхэлснийг ойлгож, улмаар Ерөнхийлөгч Д.Медведев 12-р сарын 22-нд Холбооны Хуралд тавьдаг жил тутмын илгээлтийн үеэр улс төрийн шинэчлэл хийх саналаа дэвшүүлсэн байна. Үүнд: 1. ОХУ-ын Парламентын Дээд танхим болох Холбооны зөвлөлд сонгогдох Губернаторуудыг тухайн муж бүрээс сонгогчдын шууд саналаар сонгох. 2004 оноос өмнө оросууд мужийн захирагчаа ингэж шууд сонгож байсан ба В.Путин Ерөнхийлөгч болсныхоо дараа ард иргэдийн саналаар бус, мужийн хууль тогтоох байгууллагаас сонгох зарчимд шилжүүлсэн билээ. Тухайн үед Губернаторуудын хаанчлалаас үүдэн Оросын мужуудад авилгал, гэмт хэрэг гаарсан гэж үздэг. Одоо Орос орон эргээд төвөөсөө зугтах, хязгаар мужуудыг бие даан хөгжүүлэх улс төрийн шинэчлэлийг санал болгож байна.2. Улс төрийн шинэ нам бүртгэх ажиллагаа маш олон дамжлага, хүнд суртлын шаттайг өөрчлөх, хамгийн энгийн хялбар бүртгэлийн системийг Д.Медведев санал болгож байна. 3. Зөвхөн губернаторуудыг сонгох асуудлаар төдийгүй Ерөнхийлөгчийн сонгуульд өрсөлдөгчдөд өмнөхөөс хялбар нөхцөл өгөхөө амлалаа. 4. Дараагийн Думын сонгуулийг одоогийнх шиг пропорционалиар бус, холимог системээр хийх саналыг 
дэвшүүлэв. Ингэснээр нийт 450 депутатын 225 нь нэг мандаттай тойрогт мажоритар системээр өрсөлдөж, үлдэх 225-ыг намын нэрээр авсан пропорциональ зарчмаар сонгох аж. 5. Одоогийн байгаа телевизийн суваг дээр суурилан олон нийтийн телевизийг жинхэнэ утгаар нь байгуулах санаачлагыг Д.Медведев мөн дэвшүүлсэн юм. 6. Орон нутгийн сонгуулийн штабууд, тэр дундаа Сонгуулийн Ерөнхий хороог байгуулах журмыг шинэчилнэ хэмээн бас амлалаа. Харин Д.Медведев улс төрийн шинэтгэлийг хэзээ, ямар хугацаанд хийх вэ, Ерөнхийлөгчийн сонгуулийн өмнө ямар нэг зүйл хийж чадах уу, Д.Медведев энэ бүх санаачлагуудаа зарлахын өмнө Ерөнхий сайд В.Путинтай зөвшилцсөн YY, эсвэл энэ бүх шинэтгэлийн амлалт “Нэгдсэн Орос” намын сонгуулийн өмнөх зальжин тактик уу, гэсэн асуултууд гарч ирж байна. Ямартаа ч Холбооны хуралд Ерөнхийлөгч Д.Медведевын оруулсан илгээлт улс төрийн шинэ чиг баримжааны эхлэлийг тавьж, сүүлийн парламентын сонгуулийн дараа болсон жагсаал цуглаан дээрх шаардлагууд нөлөөлөх шиг боллоо гэж үнэлж болохоор байна.

“Нэгдсэн Орос” нам сонгуулийн хуулийн мянга орчим хууль заалтыг зөрчсөн гэсэн 5 мянга гаруй гомдол ирсэн, сөрөг хүчний удирдагчдыг барьж хорьсон, судалгааны байгууллагуудын вебсайтад халдсан, утас чагнасан, сонгогчдод дарамт үзүүлсэн зэрэг зөрчлүүд илэрсэн гэж нам бус сонгуулийн хяналтын хороо болох “Дуу хоолой” судалгааны байгууллага мэдэгдсэн байна. “Нэгдсэн Орос” нам сонгуулийг луйвардсаныг батлах хангалттай баримт олноор нийтлэгдсэний нэг нь “Мой район” сонины ерөнхий редактор Дмитрий Сурнин 2011 оны 12-р сарын 5-нд “Яаж “Нэгдсэн Орос” нам 400 орчим саналыг өөр дээрээ нэмсэн бэ” хэмээх гарчигтайгаар Москвагийн сонгуулийн 1701-р тойрог дээр ажиглагчаар суусны хувьд бодит баримтанд үндэслэн интернетэд нийтэлжээ.2 ИйнхүҮ “Нэгдсэн Орос” намын төлөө өгсөн саналыг илэрхий будлиантуулсан асуудал Москва, Санкт-Петербург болон бусад хот, бүс нутгын тойргуудад ч гарчээ. Түүнчлэн Сонгуулийн Ерөнхий хорооны дүн, сонгуулийн тойргуудын протоколын бодит дүнгээс зөрж байгааг харж болно. ${ }^{3}$

\section{Результаты выборов}

Выборы депутатов Государственной Думы Федерального Собрания Российской

Федерации шестого созыва 
Дата голосования: 04.12.2011

\begin{tabular}{|c|c|c|}
\hline \multicolumn{3}{|c|}{ Наименование Избирательной комиссии } \\
\hline 1 & Число избирателей, внесенных в спшсок избирателей & 143 \\
\hline 2 & $\begin{array}{c}\text { Число избирательњых бюллетеней, полученњых участковой } \\
\text { избирательной компссией }\end{array}$ & 2000 \\
\hline 3 & $\begin{array}{c}\text { Число избирательных бюллетеней, выданных избирателям, проголосовавшпм } \\
\text { досрочно }\end{array}$ & $\mathbf{0}$ \\
\hline 19 & 1. Политическая ПарТия СПРАВЕДЛИВАЯ РОССИЯ & $\begin{array}{l}118 \\
\mathbf{8 . 9 9 \%}\end{array}$ \\
\hline 20 & 2. Политическая партия "Либерально-демократическая партия России" & $\begin{array}{c}133 \\
10.14 \%\end{array}$ \\
\hline 21 & 3. Политическая партия "ПАТРИОТЫ РОССИИ" & $\begin{array}{c}5 \\
0.38 \%\end{array}$ \\
\hline 22 & $\begin{array}{l}\text { 4. Политическая партия "Коммунистическая партия Российской } \\
\text { Федерации" }\end{array}$ & $\begin{array}{c}295 \\
22.48 \%\end{array}$ \\
\hline 23 & $\begin{array}{c}\text { 5. Политическая партия "Российская объединенная демократическая } \\
\text { партия" "ЯБЛОКО" }\end{array}$ & $\begin{array}{l}67 \\
5.11 \%\end{array}$ \\
\hline 24 & 6. Всероссийская политическая партия "ЕДННАЯ РОССИЯ" & $\begin{array}{c}662 \\
50.46 \%\end{array}$ \\
\hline
\end{tabular}

Төрийн Думын сонгуультай холбогдуулан Оросын цаашдын улс төрийн байдлын талаар гадныхан үзэл бодлоо илэрхийлсэн байна. "Путин одоохондоо давуу байдлаа хадгалж байна"4 гэж Германы "Deutsche Welle" сонины орос дахь редакцийн ерөнхий редактор, Дорнод Европын салбарын эрхлэгч Инго Маннтойфель энэ үйл явдалд зориулсан өгүүллээ нэрлэсэн байна. Түүнд “Оросын хүн амын 20\%-ийг эзэлдэг дунд анги Путины засаглал 2024 он хүртэл үргэлжилж болохыг энэ намар гэнэт ухаарч, Путин дахин ерөнхийлөгч болох нь Оросын зогсонги байдлын аюул гэж үзэж байна.” гэж өгүүлсэн байна. “Бий болж буй шинэ нөхцөл байдалд Оросын эрх баригчид хэрхэн хандаж буй тухайд янз бүрийн санал бодол дэвшүүлсээр байна. Тухайлбал, Засгийн газраа нэлээд олон буулт хийлгэхэд хүргэсэн бөгөөд энэ нь Москвагийн төвд олон хүн оролцсон жагсаал хийхийг эрх баригчид зөвшөөрөхөөс аргагүй болгосон” гэж английн “The Guardian“-ы сэтгүүлчид үзэж байна. Хятадын “Жэньминь Жибао” сонинд Хятадын орчин үеийн олон улсын харилцааны хүрээлэнгийн ажилтан Зян Ли-гийн “Медведев-Путины дэглэмийг АНУ-ын хүслээр түлхэн унагаах явдал яагаад хэрэгжих тавилангүй вэ?” гэсэн нэртэй тайлбар өгүүлэлд:” В.Путин Орост хамгийн нэр хүндтэй улс төрч хэвээр байгаa. Орост Путины эсрэг жагсаалын цар хүчийг нэмэгдүүлэх гэсэн Өрнөдийн хүсэл биелэхэд хэцүҮ санагдаж байна. ЧухамхүҮ 
В.Путин улс орныг эмх замбараагүй байдал, салан тусгаарлах ажиллагаа, сул дорой байдлаас гаргаж, эв нэгдэлтэй, тогтвортой, хүчирхэг гүрэн болох замд оруулсныг Оросын ард түмэн санаж байгаа. Оросын иргэдийн олонхи нь В.Путинд талархаж байдаг бөгөөд тэд түҮнийг дахин төрийн тэргүүн болно хэмээн найдаж, В.Путин Оросыг илүү баян, хүчирхэг болгоно гэж хүсэн хүлээж байна" гэжээ.

Харин эдгээр жагсаал цуглаануудад сөрөг хүчний удирдагч Борис Немцов оройлох Үүргийг гүйцэтгээгүй бөгөөд манхайлах үүрэгтэй оролцсон “Тийм” хөдөлгөөнийг санаачлагчдын нэг хуульч, улс төрч, А.Навальный, “Эв нэгдэл” хөдөлгөөний зохицуулагч Илья Яшин нар нь Ардчиллын төлөөх Америкийн үндэсний сан, Москва дахь Хельсинкийн бүлэглэл, Фордын сан, АНУ-ын Олон улсын хөгжлийн агентлаг (USAID) болон Соросын сангаас санхүүжигдэж байна гэж Оросын улс төрийн хүрээнийхэн үзэж байна. Энэ талаар Д.Медведев Холбооны Хуралд хэлсэн үгэндээ, “Хүн болгон хуулиар олгосон санаа бодлоо чөлөөтэй илэрхийлэх эрхтэй боловч, оросын ард түмнийг хуурч, мэхлэх, нийгмийн зөрчилдөөн Үүсгэх оролдлого нь зүйд нийцэхгүй. Иргэдийг өдөөн хатгадаг хэт туйлшрагчдыг нийгэмд өөрийн үйл хэргээ хэрэгжүүлэхийг нь таслан зогсоож, бидний үйл хэрэгт гаднаас нөлөөлөхийг бид зөвшөөрөхгүй гэж хэлжээ.

Орост төрийн Думын дүнгээр өрнөсөн үйл явдал нь энэ онд болох Ерөнхийлөгчийн сонгуулийн удиртгал мэт харагдаж байна. Оросын ард түмэн хээл хахууль, газрын тосны экспортоос хамааралтай сул дорой эдийн засаг зэргээс залхсан гэдгийг энэ сонгууль харууллаа. Оросын иргэний ухамсар ийн өөрчлөгдсөнд Оросын нийгэм шинэлэг уур амьсгал, өөрчлөлт шинэчлэлийг хүсч байгаа нь гол хүчин зүйл болж байгаа юм.

I. Оросын нийгмийн тогтвортой байдалд хийсэн дүн шинжилгээ

Тогтвортой хөгжлийг нөхцөлдүүлэгч 3 тулгуур багана нь нэгдүгээрт, эдийн засаг, хоёрдугаарт, хүрээлэн буй орчин, гуравдугаарт нийгмийн хөгжил юм. Аливаа улсын нийгэм эдийн засгийн хөгжил нь тухайн орны хүн ам зүйн бодлогоо хэрхэн боловсруулж, хэрхэн яаж хэрэгжүүлэхээс шууд шалтгаалахаас гадна эдийн засгийн хөгжилд хүн амын тоо, насны бүтэц, өсөлтийн түвшин гэсэн 3 гол хүчин зүйл нөлөөлдөг. Хүн амын өсөлт, бүтэц, болон түүнд гарч буй өөрчлөлтүүд, үйлдвэрлэл ба хэрэглээний тогтвортой бус хандлага, хүн амын 
амьжиргааны түвшингийн эрс ялгаа, ядуурал, хүрээлэн буй орчны бохирдол зэрэг хүчин зүйлсүүдийг харилцан уялдаатай авч үзэх шаардлагатай.

Хүн ам зүйн байдал.

Оросын нийт хүн амын тоо 2011 оны 11-р сарын 1-ны байдлаар 142.9 сая хүн болж, мөн оны эхэн үеэс 40.8 мян. хүнээр буюу 0.03\%-иар, харин өнгөрсөн оны мөн үетэй харьцуулахад 82,4 мян. буюу 0.06\%-иар буурсан байна. Өмнөх онтой харьцуулахад 2011 онд 1000 хүнд ногдох төрөлт 12.5 промилээр нэмэгдэж, нас баралт 13.5 пунктаар буурч, цэвэр өсөлт нь 1.0 болсон байна. Хүн амын 67,1\% нь 16-59 насны хүмүүс байгаа нь хөдөлмөрийн хангалттай нөөц байгааг харуулж байна. Хүн амын 16,3\%-ийг 15 хүртэлх насны хүүхдүүд , 17,7\%-ийг 60- аас дээш насны ахмад хүмүүс эзэлж байна. Оросын 10 хүн тутмын нэг нь 70-аас дээш настай 13,8 сая хүн буюу хүн амын 9,7\%-ийг эзэлж, хүн амын хамгийн хурдан өсч байгаа бүлэг болоод байна.

Хүн амын дунд өндөр насны 9.7 сая эмэгтэй, харин эрэгтэйчүүдийн тоо хоёр дахин бага буюу 4 сая хүн байгаа нь эрэгтэйчүүд тэтгэврийн насанд хүрэлгүй эрт нас барж байгаагаас ийм таагүй харьцаа бий болж байна. Орос улсад хөдөлмөрийн чадвартай хүн амд ноогдох хүн ам зүйн ачааллын үзүүлэлт өсч байна. Ахмад хүмүүсийн тоо ихсэх тусам төсвөөс тэтгэвэрт их мөнгө хуваарилах шаардлага гарч байна. Хөдөлмөрийн насны хүмүүс болон тэтгэврийн насны хүмүүсийн тэнцвэргүй байдал улс орны төв хэсэгт илүүтэй ажиглагдаж байна.

Хүн амын шилжих хөдөлгөөн

Том нутаг дэвсгэртэй улсын хүн ам жигд бус тархалттай бөгөөд Москва, СанктПетербург буюу “их хоолойн эдийн засагт” ойрхон хотууд руу нүүж, түлш эрчим хүчний цогцолборт харъяалалгүй бүсүүдэд хүн ам сийрэгжиж, тэр байтугаа сүүлийн 10 жилийн хугацаанд Оросын газрын зургаас 13740 тосгон, 214 хот алга болж, улсын хойд бүс нутгийн хүн ам 45\%-иар буурсан байна. 2010 оны 1-р сарын 1-ны байдлаар Төвийн бүсүүдэд оросын хүн амын дөрөвний нэг (26\%) амьдарч байгаа бөгөөд хүн амын нягтралаар хамгийн өндөр буюу нэг км.кв газарт 57 хүн (Оросын хүн амын дундаж нягтаршил - 1 кв. км-т 8,3 хүн.) ноогдож байгаа бол Якутия, Камчаткийн хязгаар, Магадан муж, Ненецк, Чукотк ба ЯмалоНенецкийн автономит тойргууд зэрэг төвөөс алслагдсан газруудад бага буюу нэг км.кв 


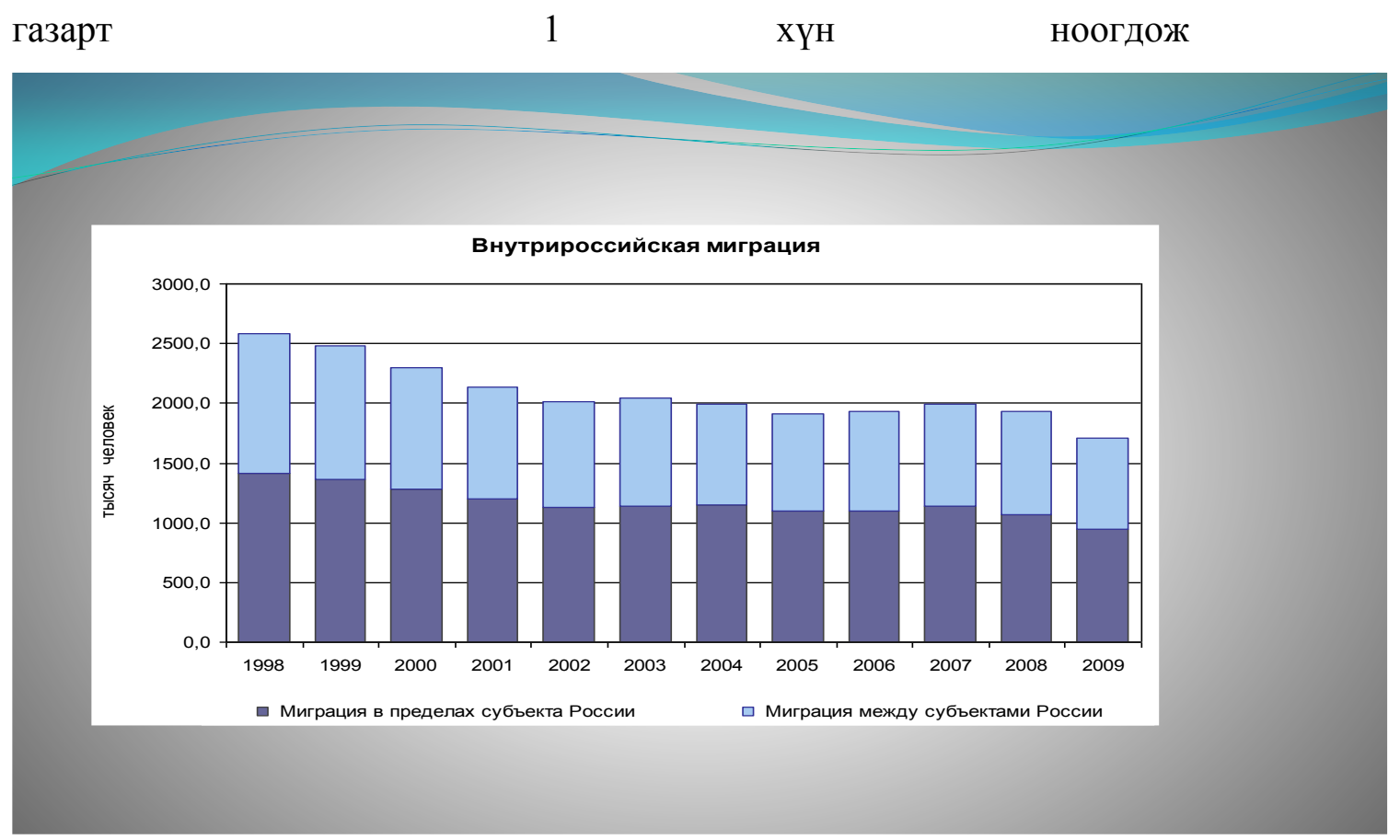

Орос улсын шилжих хөдөлгөөнд дотоод шилжилт зонхилох үүрэгтэй байна. Шилжих хөдөлгөөний хэмжээ, чиглэл нь ОХУ-ын субъектуудын хүн амын тооны хуваарилалтад онцгой нөлөө үзүүлдэг. 2003-2009 оны Бүх Оросын хүн амын тооллогын дараа дотоод шилжилтэнд нийт 15 сая хүн буюу 10 хүн тутмын 1 нь энэ хөдөлгөөнд оролцсон байна. 2001-2008 оны хооронд хүн амын дотоод шилжилт тогтворжиж, 1,9-2 сая хүн байсан байна. Шилжих хөдөлгөөн нь ихэвчлэн улсын хойд ба зүүн хэсгээс төв рүҮ чиглэж байгаа юм. Шилжин ирэгчдийн дийлэнх нь ажил эрхлэх, амжиргаагаа дээшлүүлэх, суралцах болон зах зээлд ойртох зорилгоор шилжин ирж, дээрх зорилгууд нь биелж байгаа боловч боловсролын байдалд нь ахиц гарахгүй байна.

2009 онд тус улсын гадаад шилжилт нийт шилжих хөдөлгөөний 15\%-ийг эзэлж, чухамхүү энэ үзүүлэлт хүн амын тооны өсөлтөд нөлөөлж, хуулинд өөрчлөлт оруулахад хүргэж байна. Тухайлбал, 2001 онд гадаад шилжилт буурсан нь ТУХН-ийн орнуудаас шилжин ирэгчдийн тоонд хязгаарлалт тогтоосонтой холбоотой. 2004 онд шилжин ирэгчдийн тоо сүүлийн 50 жилийн хугацаан дахь хамгийн бага үзүүлэлттэй гарчээ. 2007 онд гадаадын иргэд түр оршин суух зөвшөөрөл авах болсноор шилжин ирэгчдийн тоо 100 мянгаар буюу 54\%-иар нэмэгдсэний ТУХН-ийн гишүүн орнуудаас 96,7 мян.хүн, бусад орноос 3,9 мян. хүн байв. 2009 онд нийт шилжин ирэгчдийн 93\%-ийг (261,5 мян.хүн) нь ТУХН-ийн орнуудаас ирсэний тал нь Украин, Узбекистан, Казахстанаас (45,9 мян,хүн 42,5 
мян. 38,8 мян.хүн). ирэгсэд эзэлж байна. Шилжин ирэгчид нь боловсролын түвшин доогуур байгаагаас ядуурлын тоог нэмэгдүүлж, тэдний гол бэрхшээл нь мэргэжил, боловсролын байдлаараa үндсэн хүн амтай харьцуулахад дутмаг байгаa явдал юм.

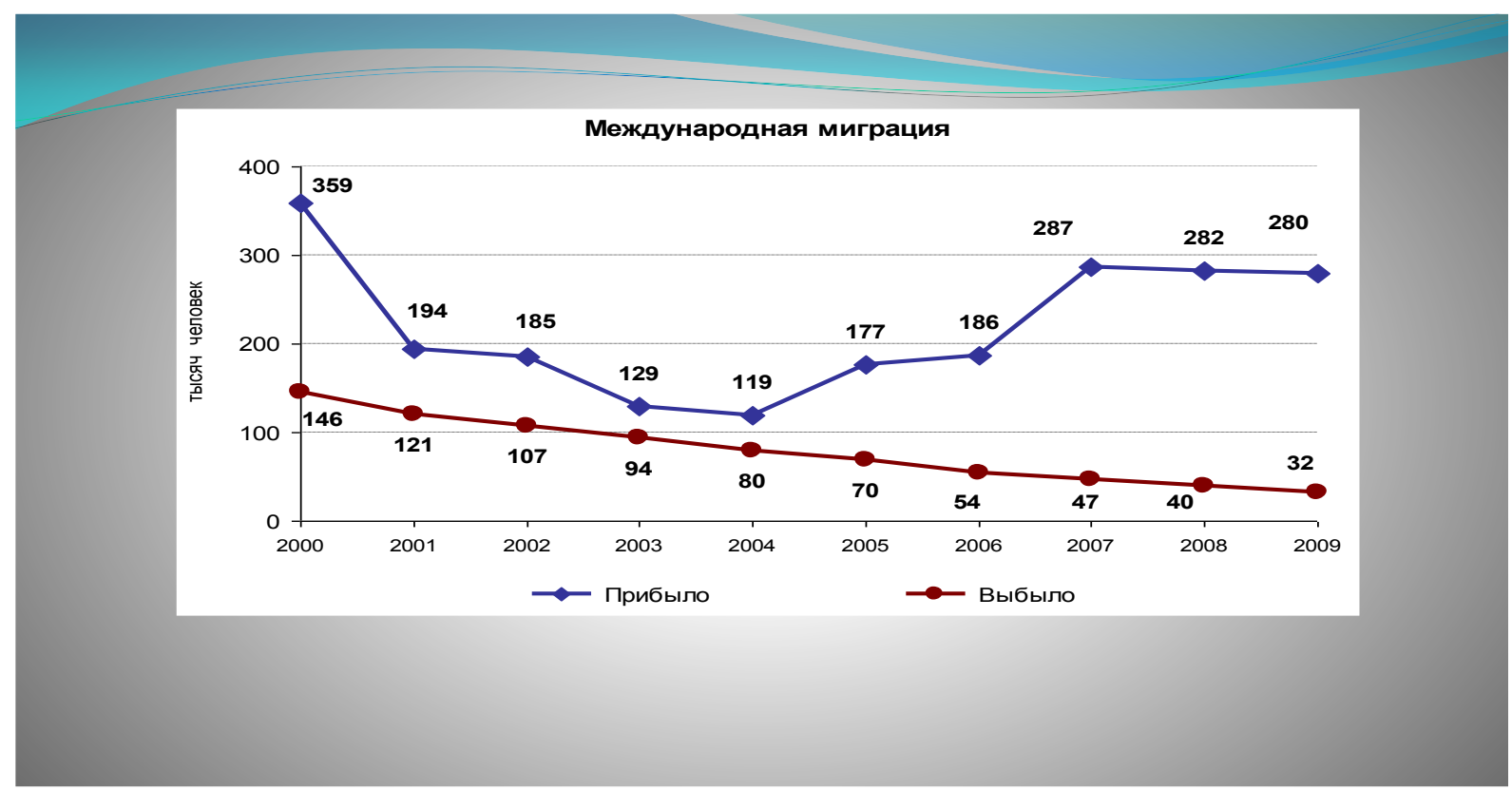

Оросын нийгмийн тулгамдсан асуудлууд

ОХУ боловсрол, эрүүл мэндийн салбарыг хөгжүүлэх, хүн ам зүй болон орон сууцны асуудлыг шийдэх зорилт тавьж, урт хугацааны үзэл баримтлалууд боловсруулан олон жилийн турш тулгамдсан асуудлуудыг шийдэж эхэлсэн ч оросын нийгмийн өмнө шийдэрлэвэл зохилтой олон асуудлууд тулгараад байна. Тухайлбал, авилга газар авсан, мөн хуулийн тогтолцоо шударга биш, нийгэм дэх улс төрийн нөлөө, оролцоо хэтэрхий их байгаа юм. Түүнчлэн санхүүгийн эх үүсвэрийн хуваарилалт буруу, дэд бүтэц, бизнесийн салбарын хөгжил, бизнес эрхлэгчдийн үйл ажиллагааг дэмжсэн хууль, эрх зүйн орчин хангалтгүй байна. Түүнчлэн Оросын Засгийн газар болон энгийн иргэд хоорондын, эсвэл төр, бизнес эрхлэгч хоёрын дундах харилцааг өөрчилж, шинэчлэх явдал тулгамдсан асуудлын нэг болоод байна.

2011 оны байдлаар Москва хот дэлхийд нэг хотод ногдох тэрбумтнуудын тоогоор тэргүүлж байна. Гэтэл Оросын олон сая жирийн ард иргэд ядуу, зүдүү амьдарч байна. Өнөөдөр 18 сая орос хүн ядуу гэх тодорхойлолтод багтсан хэвээр байна. Харин дундаж орлоготой хүмүүсийн олонхи нь ядуурлын шугам руу орох магадлал өндөр байна. Үүнд өргөн хэрэглээний бараа, бүтээгдэхүүний үнийн өсөлт хурдацтай байгаa гэх зэрэг олон 
хүчин зүйл нөлөөлж байна. Баялгийг тэгш, шударга хуваарилах зах зээлийн нөхцлийг бүрдүүлснээр Орос улсын улс төр, эдийн засгийн байдал илүҮ тогтвортой болох юм. 2010 оны ОХУ-ын Холбооны Статистикийн албанаас хүн амын дунд орлогын хуваарилалтад хийсэн судалгаагаар:

- хүн амын 13,4\% нь сарын 3422 руб.-ээс бага орлоготой, туйлын ядуу

- $\quad$ 27,8\% нь 3422-оос 7400 руб.-ийн орлоготой ядуурлын доод түвшинд

- $\quad 38,8 \%$ нь 7400-аaс 17000 руб.-ийн орлоготой ядуу

- 10.9\% нь 17000-аас 25000 руб.-ийн орлоготой ядуугаас дээш (дунд анги буюу эмч, багш, эрдэмтэд)

- 7,3\% нь 25000-аaс 50000 руб.-ийн орлоготой дундаж чинээлэг (жижиг дунд бизнес эрхлэгчид)

- 1,1\% нь 50000-75000 руб.-ийн орлоготой чинээлэг (албан тушаалтан, бизнес эрхлэгчид)

- $\quad$ 0,7\% нь 75000 руб.-аас дээш орлоготой баячууд (олигархиуд) байна.

Нийгмээс хүн амын дунд хуваарилагдаж буй орлогын хуваарилалт нь хүн амын дунд баян хоосны ялгааг зөөлрүүлэх, нийгмийн тогтвортой байдлыг хангах зорилготой байдаг. Хүн амын орлогын хуваарилалт харилцан адилгүй байгааг субъектуудээр авч үзвэл (хүснэгт хар.) байна. Нөгөө талаас, Оросын бүс нутгийн эдийн засгийн бодлогын хэрэгжилт саармаг, холбооны удирдлагын тэгш бус хандлага, субъектуудын удирдлагуудын бодлого нөлөөлж байна.

Нийгмийн зүй тогтлын онолын үүднээс хүн амын ихэнх хэсэг дунд давхраанд багтаж байвал нийгмийг тогтвортой гэж үздэг. Шинэчлэлийг хэрэгжүүлэх, нийгмийн тогтвортой байдлыг хангахын тулд их хэмжээний дундаж ангийг бүрдүүлэх шаардлагатай байдаг. Өнөөдөр Хятадад дундаж анги 18\%-ийг эзэлж байхад, АНУ-д 60\%-ийг эзэлдэг байх жишээтэй. 2011 оны 10 сард ОХУ-ын холбооны 8 тойрог, 46 субъект, 146 сууринд хийсэн санал асуулгын дүнгээр хүн амын бараг тал хувь (45,5\%) нь өөрсдийгөө дунд давхаргынх гэж үзэж байгаа бол хүн амын гуравны хоёр хувь (34.2\%) нь ажилчин давхаргад, 15\% нь өөрсдийгөө ядуу, ердөө 1\% нь өөрсдийгөө баян гэж үзсэн байна. 2010 оны мөн үетэй харьцуулахад өөрсдийгөө ядуу гэж үзэж байгаа хүн бараг хоёр дахин буурсан байна. Дээрхээс харахад хүн амын чинээлэг амьдралын түвшин жигд бус хийгээд амьдралын бүхий 
л хүрээг хамарч чадахгүй байгаa, хүн ардын байнга өсч буй материаллаг хэрэгцээ нийгмийн хоцрогдсон үйлдвэрийн аргатай зөрчилдөж байгаa, аж үйлдвэржүүлэлт, шинэчлэлт нь өөрөө урт удаан хугацааны үйл явц учир бүс нутгийн хөгжлийн ялгааг арилгахад цаг хугацаа шаардагдаж байгаa, хүн ардын дунд ядуус багагүй байгааг илтгэж байна.

Хэвлэлийн эрх чөлөө.

Үзэл бодлоо чөлөөтэй илэрхийлэх эрх чөлөөний баталгаa нь хэвлэл мэдээллийн хэрэгслээр дамжин хэрэгжиж, хэвлэлийн эрх чөлөөг бодитой болгодог. Хэвлэлийн эрх чөлөө нь олон нийтэд өөрийн улс төрийн удирдагчдын үзэл санаа болон асуудалд хандах байр суурийг нээх хамгийн сайн арга хэрэгсэл юм. Харин Оросын хөдөө, орон нутаг, мужуудад хэвлэлийн эрх чөлөөг үндсэнд нь устгасан гэхэд болно. Засгийн газарт шүүмжлэлтэй ханддаг "Новая газета" сонины Самара хот дахь салбарын редакцийн байранд цагдаа нар нэвтэрч, “майкрософтын нэг программыг зөвшөөрөлгүй ашигласан” нэрээр компъютерүүдийг нь бүгдийг нь хураан авсан байна. Мэдээлэл олж авах эрх чөлөөний төлөө тэмцсэний учир Санкт-Петербург хотын өмгөөлөгч Иван Павловыг үхтэл нь зодсон хэрэг гарсан. Москвагийн сэтгүүлчид нууц албанд байнга дуудагдан байцаагддагийн дээр шүүмжлэлт сэтгүүл зүйг байнга шахан хавчих болсны улмаас төр засгийн үйл ажиллагааг сүүдэртэй талаас нь бичсэн зүйлсийг зөвхөн интернет, вэб хуудас, блогуудаас л олж үзэхээс өөр аргагүй болжээ.

Авилга, хээх хахууль.

Олон улсын байгууллагын шинжээчдийн дүгнэлтээр Оросын шүүхийн байгууллага авилгад идэгдсэн байдлаараа Венесуэл, Чили, Конго, Марокко, Сенегалын түвшинд оччихоод байна. Авилга нь олон нийтийн албад нэн ялангуяа цагдаа, аюулгүйн стандартын байгууллагууд, боловсрол, шинжлэх ухаан, дэд бүтцийн салбарыг унагаж байна. Эдгээр салбаруудад хахуульд өгч байгаa мөнгөний дундаж хэмжээ 10000-аaс 136000 доллар болтлоо өсчээ. Ийнхүү авилгын ханш нэмэгдсэнээр хүнд суртлын үнэ өсөж, үйлчилгээг үнэгүйдүүлж, чанарыг үгүй хийж байгаа юм. Оросуудын 25\% нь нийгэм дэх хахуулийг хадгалах сонирхолтой байдаг. ЮНЕСКО-гийн мэдээлснээр, 2007 онд Оросын дээд боловсролын салбар дахь хээл хахуулийн хэмжээ 520 сая долларт хүрсэн байна.

Оросын байгалийн баялаг, түүний нийгэм, эдийн засагт үзүүлэх нөлөө 
ОХУ байгалийн баялагаар дэлхийд дээгүүр орох бөгөөд оросын эдийн засаг түүхий эд, газрын тос, байгалийн хийн олон улсын зах зээл дээрх түүхий эдийн үнийн өөрчлөлтөөс хамааралтай байдаг. Нийт төсвийн 40\%-ийг байгалийн баялагийн салбарын татвар бүрдүүлэх ба ДНБ-ний гуравны нэгийг үндсэндээ уул уурхай, ашигт малтмал, боловсруулах үйлдвэрээс бүрдүүлдэг байна. Оросын экспортын 80\%-ийг түлш ашигт малтмал, импортын 75\%-ийг аж үйлдвэрийн бүтээгдэхүүн эзлэж байна. Оросууд бараа бүтээгдэхүүн үйлдвэрлэхээсээ илүүтэйгээр, түүхий эдээ л бараагаар солиод байгаа нь харагдаж байна. Үүний эсрэг Орос улс эдийн засгийн олон тулгуурт тогтолцоог хөгжүүлэх зорилгоор нанотехнологи, нарийн технологи, мэдээллийн технологи, машин үйлдвэрлэлийн салбаруудыг ихээхэн дэмжин ажиллаж байна. Зөвхөн нанотехнологийн салбарт 5 тэрбум долларын хөрөнгө оруулалт хийж эхлээд байна. Газрын тосны наймаанаас Орос их ашиг олсон ч, хөгжингүй орнуудаас технологийн хувьд хоцорч, үйлдвэржилтийн салбарт 1970, 80-аад он буюу ЗХУ-ын үед байгуулагдсан үйлдвэрүүдийг шинэчлэх тухай асуудал онцгойлон яригдаж байна. Бүр 30,40 жилийн настай хуучин тоног төхөөрөмжийг ашигласаар байна. Газрын тосны 60\%, байгалийн хийн 40\%, Уралын нуруу, Сибир, Алс Дорнодын нутаг дэвсгэрт байна. Ерөнхийдөө нийт нөөцийн бараг тал хувь нь өнөөгийн техникийн нөхцөлд ашиглах боломжгүй байна. Газрын тосны гарц жилээс жилд багасч байгаа бөгөөд Оросын газрын тосны гарц жилд 110 сая тн байснаа 100 сая тн болоод 2020 он гэхэд 90 сая тн болж буурна гэж шинжээчид үзэж байна. Түүнчлэн Оросын өмнө газрын тосны үнийн уналт, барууны зүгээс баримталж буй бодлого, Орос-Америкийн харилцааны онцлогоос хамаарах асуудлууд тулгарч байна. Энэ нь ирээдүйд Азийн эрчимтэй хөгжиж байгаа орнуудын түүхий эдийн хавсарга болгох вий гэсэн болгоомжлол төрүүлж байна.

Дэлхийд хамгийн томд орох Оросын эрчим хүчний салбарын компаниуд, түүхий эдийн үнэ өссөнөөр орлого нь нэмэгдэж, рекорд тогтоох болсон ч арилжааны зогсонги байдал, мөнгөн тэмдэгтийн ханшийн уналт, хууль тогтоомжийн өөрчлөлт зэргээс сэргийлэн гадаадад хувьцаагаа гаргах сонирхол улам нэмэгдэх болсон байна. Энэ нь нөгөө талаас эх орныхоо улс төрийн тогтвортой байдалд итгэлгүй байгаагаа харуулж байгаа юм. Оросын томоохон алтны компани "Polyus Gold", өнгөрсөн оны 7 сард Москвагийн хөрөнгийн биржид бүртгэлтэй байсан хувьцаагаа Лондонгийн хөрөнгийн бирж рүү шилжүүлсэн бол фосфотын бордоо үйлдвэрлэлээр улсдаа дээгүүрт ордог “Phosagro” компани мөн адил арга 
хэмжээ авсан байна. Хөгжиж буй эдийн засагтай орнуудаас Лондонгийн хөрөнгийн бирж дээр хувьцаагаа гаргадаг 4 улсын нэг бол Орос бөгөөд элсэн чихэр үйлдвэрлэгч "Rosagro Plc", Оросын хамгийн том хайлтын системийн оператор "Yandex NV" компаниудын хувьцааны борлуулалт, Лондон, Нью Иоркийн хөрөнгийн бирж дээр 2011 онд тэргүүлж, нийтдээ 5 тэрбум ам.долларын орлоготой ажилласан байна. Лондонгийн хөрөнгийн бирж дээр 30 өдрийн дунджаар өндөр ханштайгаар борлуулагдаж буй хувьцаануудын 10 нь Оросын томоохон компаниудын үнэт цаас байна.

Дүгнэлт

Орост шударга сонгууль, улс төрийн нөлөөллөөс хараат бус шүүхийн тогтолцоо, чөлөөт хэвлэл, авилгын эсрэг хийж буй тууштай тэмцэл дутагдаж байгаа нь энэ бүхнээс тод харагдаж байна. Орос орны ардчилсан нийгэмд шилжсэн шилжилтийг Б.Ельцин “олигархийн капитализм” руу гажуудуулж, зах зээлийн эдийн засгийн үр шимийг цөөн тооны олигархиуд хүртэх болсон төдийгүй тэд ардчиллыг бүхэлд нь худалдан авч, төр зөвхөн тэдний эрх ашгийг хамгаалах төдий зүйл болсон. Харин В.Путин засгийн эрхэнд гарснаар олигархиудыг хязгаарлах бодлого явуулж эхэлсэн боловч, энэ нь нөгөө талдаа “бюрократын капитализм”-ыг бий болгосон. Өөрөөр хэлбэл, баялагийг зах зээл бус төр хуваарилан шийдэж, төртэй холбогдохгүйгээр бизнес баталгаагүй, эрсдэлтэй болсон бөгөөд зах зээл дээр ашигтай бизнесийг гагцхүү төр л хийх ёстой гэж ойлгоход хүргэсэн. Ерөнхийлөгч Д.Медведев 2011 оны зун Санкт-Петебург хотод болсон олон улсын эдийн засгийн XV чуулганы хүрээнд хэлсэн үгэндээ:”Сүүлийн хэдэн жил улс орны эдийн засагт улсын оролцоо нэмэгдсэн, гэхдээ энэ нь 90-ээд оны эмх замбараагүй байдлыг тогтворжуулахын тулд зайлшгүй хийгдсэн. Ихэнх салбарт улсын үйлдвэрүүд давамгайлж байгаа нь Оросын эдийн засаг өрсөлдөх чадвараа алдаж болох юм.” гэж мэдэгдсэн. Иймд Оросын нийгмийн тогтвортой байдлыг хангахад бодит эдийн засгийн болон цэвэр улс төрийн өрсөлдөөнийг бий болгох явдал юунаас чухал байгаа мэт сэтгэгдэл төрж байна.

\section{АШИГЛАСАН МАТЕРИАЛУУД:}

1. http://ru.wikipedia.org/wiki/Государственная_дума 
2. Д.Сурнин. Как “Единая Россия" прибавила себе почти 400 голосов.// http://www.russian.rfi.fr/rossiya/20111205-kak-edinaya-rossiya-pribavila-sebe-pochti-400golosov

3. Цифры в протоколах на участке резко расходятся с данными с этого же участка на сайте ЦИК: такие нарушения легче всего доказать. И их много. Forbes собирает и анализирует информацию о них.//

http://www.forbes.ru/sobytiya/vlast/77204-vybory-2011-kollektsiya-narushenii

4. Г.П.Литвинцева,Е.А.Стукаленко,О.В.Воронкова.Оценка неравенства денежных доходов населения России с учетом покупательной способности рубля в регионах.// Вестник российского научного гуманитарного фонда. М.2011.1․ Стр. Инго Маннтойфель. Путин пока еще сохраняет преимущество.

http://www.dw-world.de/dw/article/0,,15644191,00.html 